\title{
Dobrowolność czynnego żalu związanego z usiłowaniem udolnym i nieudolnym (uwagi na tle uchwały siedmiu sędziów SN z dnia 19 stycznia 2017 r., I KZP 16/16')
}

\begin{abstract}
The following article critically assesses the ruling of seven justices of the Supreme Court dating January 19, 2017. The crucial issue undertaken by this article consists in the assessment of the validity of the ruling of the Supreme Court which assumes an unsuccessful attempt in the cases of the lack of an object on which to commit a criminal offense and defines the "voluntariness" of active grief exhibited at the stage of attempting to commit a criminal offense. The Supreme Court assumed an objectivist conception in their interpretation of the phrase "lack of an object on which to commit a criminal offense", thus assuming that what transpires is a successful attempt in the case where there was a lack of a particular object comprising the perpetrator's intent, but there were other objects which could have become the objects of the crime. At the same time, however, the Supreme Court ruled that the premises of voluntariness resulting in impunity (Article 15 $\S 1$ of the Criminal Code) did not apply, since the perpetrator did not abandon his intent to commit a criminal offense; it was only the object of it that did not fulfill their expectations. According to the author of the article, such a ruling allows to reach two contradictory conclusions. Thus, the author proposes a different conception of assuming successful or unsuccessful attempt with regard to an object on which to commit a criminal offense, as well as a model for assessing the voluntariness of the perpetrator in the cases of the lack of continuation of iter delicti.
\end{abstract}

Key words: active grief, attempt, voluntary withdrawal

${ }^{1}$ Uchwała siedmiu sędziów SN z dnia 19 stycznia 2017 r., I KZP 16/16. Źródło: http:// www.sn.pl/sites/orzecznictwo/Orzeczenia3/I\%20KZP\%2016-16.pdf [dostęp: 27.02.2017]. 
Rozstrzygając rozbieżności w wykładni prawa występujące w orzecznictwie SN oraz sądów powszechnych, w uchwale z dnia 19 stycznia 2017 r. SN orzekł, iż „1) Zawarte w art. 13 § 2 k.k. wyrażenie »brak przedmiotu nadającego się do popełnienia na nim czynu zabronionego « oznacza brak takiego przedmiotu, który należy do zbioru desygnatów znamienia przedmiotu czynności wykonawczej typu czynu zabronionego, do którego zmierzał sprawca. 2) Pociągnięcie do odpowiedzialności karnej sprawcy usiłowania nieudolnego (art. 13 § 2 k.k.) może być in concreto uwarunkowane poczynionymi ustaleniami co do zamiaru popełnienia czynu zabronionego na określonym przedmiocie". Uchwała SN podjęta została na wniosek Pierwszego Prezesa SN o rozstrzygnięcie rozbieżności w wykładni prawa w zakresie dotyczącym następującego zagadnienia prawnego: „czy brak przedmiotu nadającego się do popełnienia na nim czynu zabronionego, o którym mowa w art. 13 \$ k.k., oznacza brak jakichkolwiek desygnatów znamienia przedmiotu czynności wykonawczej, na których chociażby potencjalnie może zostać popełniony czyn zabroniony w konkretnym stanie faktycznym, czy jedynie brak desygnatów, na które nakierunkowany jest zamiar sprawcy?".

Wskazana przez SN wykładnia, chociaż dotyczy problematyki rozgraniczenia usiłowania udolnego i nieudolnego, w pewnej mierze odnosi się również do kwestii czynnego żalu związanego z usiłowaniem i dotyka problemu dobrowolności. I chociaż to ten ostatni aspekt znajduje się w polu mojego zainteresowania, nie można pominąć rozważań SN odnośnie do wytyczania granicy pomiędzy usiłowaniem udolnym i nieudolnym. Czynny żal okazany na etapie usiłowania jest bowiem bardzo silnie związany z tym stadium iter delicti - kształt, przesłanki, postać i rodzaj usiłowania ma bezpośredni wpływ na przesłanki i karnoprawne konsekwencje czynnego żalu.

Sąd Najwyższy zważył, iż usiłowanie nieudolne ma podstawowe cechy usiłowania udolnego (zamiar, bezpośrednie zmierzanie do dokonania, brak dokonania), ale między obiema postaciami zachodzi zasadnicza różnica strukturalna - o ile przy usiłowaniu udolnym dokonanie było potencjalnie możliwe, to w przypadku usiłowania nieudolnego dokonanie nigdy nie może nastąpić. Jedną z przyczyn ,jałowego” zachowania sprawcy (jak określił to SN) jest urojenie, że na drodze realizacji zamiaru jest przedmiot nadający się do popełnienia na nim czynu zabronionego.

Warto już w tym miejscu poczynić pierwszą uwagę. W tezie przywołanej uchwały SN posługuje się sformułowaniem „przedmiot czynności wykonawczej” jako swoistym synonimem pojęcia „przedmiot nadający się do popełnienia na nim czynu zabronionego". To prawda, że w piśmiennictwie sformułowania te stosowane są zamiennie, pamiętać jednak należy, że ustawa posługuje się wyłącznie tym drugim (vide art. 13 
§ 2 k.k.). Jeśli konstatacja SN ma mieć szersze znaczenie (a nie odnosić się wyłącznie do zaboru rzeczy), to nieodzowne staje się pytanie, czy rzeczywiście „przedmiot czynności wykonawczej” jest synonimem pojęcia „przedmiot nadający się do popełnienia na nim czynu zabronionego”. Warto więc zauważyć, że w literaturze ${ }^{2}, \mathrm{w}$ wąskim co prawda zakresie, poruszane jest zagadnienie, czy przedmiot wykonawczy występuje w każdej typizacji ${ }^{3}$. Wypowiedzi na temat samego przedmiotu wykonawczego też nie są zbyt obszerne i pogłębione. Według A. Zolla przedmiot wykonawczy to obiekt będący nośnikiem dobra prawnego, stanowiącego znamię określonego typu czynu zabronionego ${ }^{4}$. Nie ma wątpliwości, że w przypadku przestępstw przeciwko mieniu nośnik wspomnianego dobra będzie rzeczywiście równocześnie przedmiotem nadającym się do popełnienia na nim czynu zabronionego. $Z$ pewnością jednak istnieją i takie typizacje, gdzie nie występuje w ogóle nośnik dobra prawnego lub jest on różny od przedmiotu, na którym czyn jest popełniany. W moim przekonaniu przykładem takiej sytuacji jest łapownictwo. Przedmiotem ochrony, dobrem prawnym tego przestępstwa jest właściwe, bezstronne, wolne od nacisków funkcjonowanie wybranych obszarów państwa. Wręczane i przyjmowane w ramach np. pełnienia funkcji publicznej pieniądze nie stanowią przedmiotu czynności wykonawczej, ponieważ nie są nośnikiem dobra prawnego stanowiącego ustawowe znamię czy, innymi słowy - substratem przedmiotu ochrony. Pieniądze takie są jednak przedmiotem nadającym się do popełnienia na nim czynu zabronionego (lub ewentualnie środkiem do jego popełnienia). Przyjęcie zatem koperty wypełnionej ścinkami gazet, $\mathrm{w}$ przekonaniu, że są to pieniądze, $\mathrm{w}$ związku z pełnieniem funkcji publicznej jest usiłowaniem nieudolnym, mimo że z istoty typizacji łapownictwa i jej dobra prawnego wynika, że brak jest przedmiotu czynności wykonawczej.

SN przytacza także powtarzaną często tezę, iż błąd w przypadku usiłowania nieudolnego ma „odwrotny kierunek w stosunku do kategorii błędów, które na podstawie art. 28-30 k.k. wyłączają odpowiedzialność karną". Zastanawia nieco niezwykła akceptacja takiego ujęcia. Pierwszą rzeczą jest wątpliwość, czy błąd w ogóle może mieć kierunek. Nawet gdyby przyjąć, iż jest to ujęcie nieco metaforyczne, to jednak istota zróżnicowania skutków błędu przewidzianego w art. 13 § 3 oraz art. 28-30 leży zgoła

2 Por. np.: I. Andrejew: Polskie prawo karne. Warszawa 1971, s. 103; W. Wróbel, A. Zoll: Polskie prawo karne. Warszawa 2010, s. 202; O. Sitarz: Czynny żal zwiazzany z usiłowaniem $w$ polskim prawie karnym. Analiza dogmatyczna i kryminalnopolityczna. Katowice 2015, s. 203.

${ }^{3}$ Stąd podział - wyjątkowy - przestępstw na przechodnie i nieprzechodnie - por. R.G. Hazas. W: Prawo karne. Red. A. GrześKowiak. Warszawa 2012, s. 119.

${ }^{4}$ A. Zoll. W: Kodeks karny. Komentarz. T. I. Red. A. Zoll. Warszawa 2012, s. 261. 
gdzie indziej. Punktem wyjścia późniejszego zróżnicowania jest zamiar w przypadku usiłowania sprawca ma zamiar dokonać określonego czynu zabronionego, jednak na skutek błędu mu się to nie udaje. W sytuacjach określonych $\mathrm{w}$ przepisach art. 28-30 wręcz przeciwnie - sprawca takiego zamiaru nie ma, ale na skutek błędu dochodzi do naruszenia normy prawnokarnej. W każdym z tych przypadków błąd spowodował zmianę kierunku realizacji zamierzeń sprawcy. Odrębną kwestią jest karnoprawna ocena znaczenia błędu dla odpowiedzialności karnej. Nie ma tu jednoznacznych, prostych i „symetrycznych” reguł i wcale być nie musi, ponieważ ostatecznie są to zupełnie odmienne sytuacje, o różnym rozłożeniu elementów obiektywnych i subiektywnych. Nie ma jednak wątpliwości, że zasadniczym problemem budzącym spory w doktrynie, jak i powodującym brak jednolitości $\mathrm{w}$ orzecznictwie jest kwestia braku przedmiotu nadającego się do popełnienia czynu zabronionego, który to brak uniemożliwił dokonanie czynu zabronionego.

Sąd Najwyższy uznał, że (systemowa) specyfika usiłowania nieudolnego przejawia się w obiektywnej niemożności dokonania czynu zabronionego, którą powiązać należy z „brakiem przedmiotu nadającego się do popełnienia na nim czynu zabronionego". Natomiast wykładnia językowa i systemowa pojęcia „czyn zabroniony” doprowadziła SN do przekonania, iż przytoczone wyżej sformułowanie, zaczerpnięte z treści przepisu art. $13 \S 2$ k.k., oznacza, że na drodze zmierzającej do dokonania sprawca nie napotka żadnych desygnatów znamienia przedmiotu czynności wykonawczej typu przestępstwa, które zamierza popełnić.

Trafnie zdiagnozował problem J. Giezek. Jak zauważa, rzecz pozornie wydaje się nieskomplikowana, ponieważ odpowiedź na pytanie o brak przedmiotu sprowadza się do prostego aktu poznawczego, rozstrzygającego, czy w otaczającej rzeczywistości dany akt postrzegamy czy też nie ${ }^{5}$. Ustawa (w art. $13 \S 2$ k.k.) jednak mówi o przedmiocie nadającym się do popełnienia na nim czynu zabronionego.

Zdaniem J. Giezka realnie istniejący przedmiot, na który potencjalnie skierowane jest działanie sprawcy - ze względu na krzyżowanie się obiektywnej i subiektywnej płaszczyzny oceniania - może się okazać: 1) obiektywnie i subiektywnie zdatny do popełnienia na nim czynu zabronionego; 2) tylko obiektywnie zdatny, subiektywnie niezdatny; 3) tylko subiektywnie zdatny, obiektywnie zaś niezdatny; 4) zarówno obiektywnie, jak i subiektywnie niezdatny do popełnienia na nim czynu zabronionego. Wątpliwości dotyczą sytuacji, w której ocena subiektywna nie pokrywa się z oceną obiektywną. J. Giezek proponuje, aby formułowanie

${ }^{5}$ J. GiezeK. W: Kodeks karny. Część ogólna. Komentarz. Red. J. GiezeK. Warszawa 2012, s. $126-127$. 
oceny zdatności przedmiotu opierało się łącznie na obiektywnym i subiektywnym punkcie widzenia („obiektywizacja oceny subiektywnej”). Innymi słowy, tzw. subiektywna ocena sprawcy usiłowania winna być konfrontowana z modelem racjonalnego oraz praktycznie zachowującego się sprawcy. Dlatego też J. Giezka nie dziwi rezygnacja z zaboru monety pięciozłotowej, skoro nie jest ona przedmiotem, dla którego „warto” byłoby dopuszczać się rozboju ${ }^{6}$. Wydaje się jednak, że dość ryzykowna jest figura „racjonalnie” czy też „pragmatycznie” zachowującego się sprawcy, a środki masowego przekazu skutecznie przekonują, że dla niejednego sprawcy „warto” dokonać przestępstwa dla papierosów czy bardzo małej kwoty.

Zupełnie inaczej do kwestii tej podszedł J. Majewski. Jego zdaniem właściwe rozeznanie istoty kryterium możliwości/braku możliwości dokonania czynu zabronionego stanowi solidny punkt oparcia dla prawidłowego $^{7}$ rozstrzygania o kwalifikacji przynajmniej niektórych skomplikowanych stanów faktycznych. Punktem wyjścia musi być ustalenie znaczenia terminu „czyn zabroniony”, jako składnika definicji użytej w przepisie art. $13 \S 2$ k.k. Termin „czyn zabroniony” w przywołanym przepisie mógłby być - zdaniem autora - teoretycznie wykładany trojako: 1) jako odnoszący się do braku możliwości dokonania ściśle oznaczonego czynu zabronionego; 2) jako odnoszący się do braku możliwości dokonania jakiegokolwiek czynu zabronionego określonego typu (kradzieży, zabójstwa itp.); 3) jako odnoszący się do braku możliwości dokonania jakiegokolwiek czynu zabronionego jakiegokolwiek typu. Zdaniem J. Majewskiego zawarty w art. 13 \$2 zwrot ,dokonanie [czynu zabronionego - O.S.] jest niemożliwe" odnosi się do dokonania tego ściśle oznaczonego czynu zabronionego, który stanowi przedmiot zamiaru sprawcy (powołując się na analogiczną sytuację wskazaną w przepisie art. 13 \$ 1 , w którym ustawodawca, posługując się odpowiednimi zaimkami, bez wątpienia wskazuje, że czyn zabroniony, do którego sprawca zmierza, oraz czyn zabroniony stanowiący przedmiot zamiaru sprawcy to ten sam czyn zabroniony) ${ }^{8}$.

Wydaje się, że prezentowany przez J. Majewskiego sposób wykładni pojęcia „czyn zabroniony” nie narusza zakazu wykładni homonimicznej (przed czym przestrzega w przywołanej uchwale SN), albowiem interpretator nie tyle nadaje sformułowaniu „czyn zabroniony” różne znaczenia,

${ }^{6}$ J. Giezex: Glosa do uchwały Sądu Najwyższego z dnia 20 listopada 2001 r., sygn. I KZP 36/2000. Prok. i Pr. 2001, nr 9, s. 105-111.

${ }^{7}$ Pytanie jednak, zadane na marginesie, brzmi, co to znaczy prawidłowe rozstrzygnięcie - zgodne z intuicją, poczuciem sprawiedliwości czy też polityką karną.

${ }^{8}$ J. MAJEWSKI: O różnicy i granicy między usitowaniem udolnym a usitowaniem nieudolnym. W: Formy stadialne i postacie zjawiskowe popetnienia przestępstwa. Materiaty III Bielańskiego Kolokwium Karnistycznego. Red. J. Majewski. Toruń 2007, s. 33-51. 
co operuje na różnych poziomach jego konkretyzacji. Co więcej przepis art. 13 k.k. nie jest jedynym, który wymaga takiego zróżnicowania interpretacyjnego (por. przykładowo przepis art. 18 \$ 2 i 3 k.k.).

Skrajna obiektywizacja, a chyba tak należy ocenić stanowisko SN, doprowadzić może do wniosku, iż usiłowanie nieudolne ze względu na brak przedmiotu nadającego się do popełnienia na nim czynu zabronionego w rzeczywistości praktycznie nigdy nie nastąpi.

SN wyraził przekonanie, że „kryminalizując usiłowanie w obu jego postaciach w zależności od tego, czy dokonanie jest możliwe czy niemożliwe, a więc zagrażające bądź niezagrażające dobru prawnemu, racjonalny ustawodawca formułował przepisy art. 13 \$ 1 i 2 k.k. tak, by granica modelowa między udolnością a nieudolnością nie mogła być zrelatywizowana do zamiaru sprawcy mogącego przybrać różny kształt zależnie od konkretnych okoliczności czynu, wyłaniających się w fazie zmierzania do dokonania". Z takim stanowiskiem trudno się zgodzić. Usiłowanie to forma stadialna, cechująca się bardzo silnym „zrelatywizowaniem do zamiaru". To właśnie zamiar pozwala ocenić, czy określone zachowanie prezentowane przez sprawcę jest przygotowaniem, usiłowaniem czy dokonaniem. Przykładowo to samo zniszczenie drzwi „zrelatywizowane do zamiaru" może być przygotowaniem do dokonania zabójstwa, usiłowaniem kradzieży z włamaniem lub po prostu dokonaniem zniszczenia mienia (odrębną kwestią jest karnoprawna ocena każdej z wymienionych sytuacji). Trudno więc racjonalnie ten subiektywny element instytucji usiłowania wyeliminować, czy też znacząco zminimalizować. Ponownie wrócić należy więc do tezy J. Majewskiego i zadać pytanie, o jaki - zamierzony przez sprawcę - czyn zabroniony chodzi.

Inną sprawą jest postać tego zamiaru, a przede wszystkim wynikające $\mathrm{z}$ charakteru tego elementu trudności dowodowe. Niejednokrotnie bowiem sprawcy (zwłaszcza przy przestępstwach przeciwko mieniu, ale też przeciwko zdrowiu) towarzyszy zamiar dość ogólnikowy, słabo sprecyzowany. Ponadto właśnie ze względu na brak dokonania i skróconą iter delicti, a co za tym idzie mniejsze ,quantum" przedmiotowych/zewnętrznych elementów czynu, ustalenie zamiaru i jego punktu odniesienia w postaci skonkretyzowanego przedmiotu może być wręcz niemożliwe. Być może właśnie wspomniane trudności dowodowe sprawiają, iż silnie akcentowane są elementy obiektywne usiłowania.

W dalszej części pomocniczo SN powołał się na wykładnię historyczną, wskazując na zmieniającą się treść stosownych przepisów w kodeksach karnych z lat 1932, 1969 i 1997. Szczególną wagę SN przyłożył do pominięcia przez ustawodawcę z 1997 r. sformułowania „zamierzonego czynu" odnośnie do usiłowania nieudolnego, co ma świadczyć o pewnym procesie obiektywizacji instytucji usiłowania. To prawda, od czasów pro- 
jektu instytucji usiłowania zaproponowanego przez J. Makarewicza można zauważyć silniejsze akcentowanie elementów obiektywnych tej instytucji, jednak wskazane zmiany w tekście ustawy zostały przez SN mylnie odczytane. Warto przede wszystkim zwrócić uwagę na samą deklarację projektodawcy, który w uzasadnieniu do Kodeksu karnego wskazał, iż „Kodeks karny z 1997 r. nie przewiduje wprowadzenia merytorycznych zmian w stosunku do sposobu określania w Kodeksie karnym z 1969 r. usiłowania nieudolnego. Proponowane zmiany służą jedynie zwiększeniu precyzji w określaniu usiłowania nieudolnego" 9 .

Przyjęcie określonej koncepcji nie tylko ma znaczenie dla ostatecznej decyzji co do rodzaju usiłowania (przyjęcie w kwalifikacji usiłowania udolnego lub nieudolnego, a w związku $\mathrm{z}$ tym ewentualne zastosowanie instrumentów, o których mowa w art. 14 § 2 k.k.). Wybór określonego zapatrywania radykalnie wpływa na sytuację sprawcy na płaszczyźnie czynnego żalu. Jeżeli bowiem sprawca nie dokonuje kradzieży, ponieważ nie ma interesującego go przedmiotu, to taka rezygnacja odczytana być może w sposób dwojaki - właśnie w zależności od przyjętej koncepcji. Jeśli uznamy, że o właściwości przedmiotu decyduje zamiar sprawcy, a zatem rezygnuje z kradzieży - mamy do czynienia z usiłowaniem nieudolnym, a poniechane przez niego działania nie mają cechy dobrowolności, nie można więc mówić o czynnym żalu. Zupełnie inaczej wygląda sytuacja, w której uznamy, że zdatność do bycia przedmiotem ma charakter obiektywny, niezależny od sprawcy. Wówczas rezygnacja z kradzieży takich przedmiotów może mieć charakter dobrowolny, a to już otwiera drogę do rozważenia instytucji czynnego żalu, gwarantującej bezkarność.

SN bardzo znamiennie kwestię tę przeprowadził. Stanął bowiem na stanowisku koncepcji obiektywistycznej przy wykładni sformułowania „brak przedmiotu nadającego się do popełnienia na nim czynu zabronionego", zatem przyjął, iż chodzi o usiłowanie udolne w sytuacji, gdy brak było określonego przedmiotu objętego zamiarem sprawcy, ale znajdowały się inne przedmioty mogące stać się przedmiotem zaboru. Równocześnie jednak uznał, iż nie zostały zrealizowane przesłanki dobrowolności skutkujące bezkarnością (art. $15 \S 1$ k.k.), albowiem sprawca nie porzucił zamiaru dokonania czynu zabronionego, a jedynie obiekt nie spełniał jego oczekiwań.

Zasadniczym zatem zagadnieniem oceny zasadności stanowiska SN staje się pojęcie dobrowolności i jego istota. Wagę tego pojęcia podkreślał

${ }^{9}$ Nowe kodeksy karne - z 1997 r. z uzasadnieniami. Kodeks karny. Kodeks postępowania karnego. Kodeks karny wykonawczy. Warszawa 1997, s. 124-125. O znaczeniu innych zmian przepisów odnośnie do usiłowania w dwudziestowiecznych kodeksach por.: O. Sitarz: Czynny żal..., s. 120-125. 
Z. Kubec, pisząc, że jest to najważniejszy i najtrudniejszy problem ${ }^{10}$. Jest to właściwie jedyne kryterium pozwalające na rozróżnianie usiłowania zatamowanego (karalnego jak dokonanie) i zaniechanego (bezkarnego). Albowiem, jak wskazywał S. Budziński, „dwie są bowiem przyczyny, dla których człowiek zawiesza rozpoczęte działanie: nie chcieć lub nie móc"11.

Ustawodawca w żaden sposób nie sprecyzował warunków czy przesłanek tej dobrowolności, w szczególności nie wskazał motywacji sprawcy, która miałaby warunkować bezkarność. Niemniej w literaturze i orzecznictwie spotkać można wiele interpretacji tego pojęcia. Klasyfikację tych znaczeń sporządził A. Spotowski, który dokonał podziału ujęcia dobrowolności na psychologiczne i normatywne. Według pierwszego nie ma znaczenia charakter motywu skłaniającego sprawcę do odstąpienia od usiłowania, lecz wystarcza, aby według swego wyobrażenia mógł on dokonać przestępstwa, lecz nie chciał tego uczynić. Zgodnie z ujęciem normatywnym pojęcie dobrowolności ma swoisty charakter i związane jest $\mathrm{z}$ oceną motywów odstąpienia ${ }^{12}$. Ujęcie psychologicznie trafnie oddaje znana formuła R. Franka, w myśl której o dobrowolności może być mowa, gdy sprawca mówi: „nie chcę osiągnąć celu, nawet jeśli mogę”, natomiast zdanie: „nie mogę dojść do celu, nawet gdybym chciał" oznacza brak dobrowolności ${ }^{13}$. I nie ma wątpliwości, że znakomita większość karnistów przedstawia taki punkt widzenia, podobnie jak judykatura. Przykładowo W. Wolter wskazywał, że „,warunek ustawy jest minimalistyczny", wystarcza, że sprawca nie chciał więcej dokonać przestępstwa ${ }^{14}$. Powołując się zaś na E. Krzymuskiego, W. Radecki dodaje, że dla prawa karnego obojętne jest, czy ktoś nie jest przestępcą z przekonania czy ze strachu oraz to, czy ktoś odstąpił od dokonania przestępstwa wskutek skruchy czy też z obawy przed karą ${ }^{15}$. Podobne stanowisko prezentuje wielu innych autorów ${ }^{16}$. Przeglądu konsekwentnego w tym zakresie orzecznictwa Sądu Najwyższego do 1981 r. dokonał już

10 Z. Kubec: Kilka uwaga na temat odstapienia od usitowania. PiP 1969, nr 3, s. 565.

11 S. Budziński: Wykład porównawczy prawa karnego. Warszawa 1988, s. 174 za: A. Stefański: Dobrowolne odstapienie od usitowania. Prok. i Pr. 1996, nr 4, s. 112.

12 A. Spotowsкi: O odstapieniu od usiłowania. PiP 1980, nr 6, s. 91-93.

13 Za: A. Spотоwsкi: O odstapieniu od usiłowania..., s. 92.

14 W. Wolter: Nauka o przestępstwie. Warszawa 1973, s. 273.

15 W. RADECKI: Prawne i moralne oceny czynnego żalu. Pal. 1976, nr 12, s. 22-25.

16 S. ŚLIwiński: Prawo karne. Warszawa 1946, s. 307; G. RejMAN: W kwestii dobrowolnego odstapienia od usiłowania. NP 1969, nr 3, s. 436-439; W. Wolter: Nauka o przestępstwie..., s. 273; W. Kubala: Glosa do wyroku Izby Karnej Sąu Najwyższego z 1 sierpnia 1975 r. Pal. 1976, nr 4-6; J. Raglewski: Dobrowolne odstapienie od czynu jako przestanka instytucji czynnego żalu. Prok. i Pr. 1997, nr 3, s. 43; W. Wróbel, A. Zoll: Polskie prawo karne..., s. 237; J. WarYlewski: Prawo karne. Część ogólna. Warszawa 2012, s. 355. 
W. Kubala ${ }^{17}$; przykłady orzeczeń późniejszych wskazuje A. Stefański ${ }^{18}$. Współczesną ilustracją podejścia władzy sądowniczej do tego zagadnienia stać się może teza wyroku SA w Krakowie o następującej treści: „1. Odstępuje dobrowolnie od usiłowania ten, kto mogąc kontynuować je, rezygnuje z niego, bo nie chce już osiągnąć zamierzonego wcześniej celu. 2. Dla stwierdzenia dobrowolności odstąpienia od usiłowania nie ma znaczenia powód takiego zachowania. Sprawca nie musi zrozumieć naganności swego działania, wyrządzonej krzywdy itd., by dobrowolnie odstąpić od usiłowania. Praktyka sądowa ujawnia rozmaite motywacje takich postąpień, od najbardziej szlachetnych przez moralnie obojętne aż po wątpliwe. W każdym z tych wypadków stosowanie art. $15 \S 1$ k.k. jest słuszne, a zwłaszcza celowe, bo sprzyja zmniejszeniu krzywdy ofiary przestępstwa i skłania innych sprawców do naśladowania, również z korzyścią dla ofiar przestępstw"19.

Odmienne podejście prezentuje M. Szerer, uznając, że w słowach przepisu o czynnym żalu nie ma nic, co by upoważniało do tego, aby dekryminalizację dobrowolnego odstąpienia od usiłowania wiązać z oportunizmem. Podkreślał on, że nie miałoby karnopolitycznego sensu, gdyby sprawcy surowo ocenianych przestępstw (np. zgwałcenia) ustawowo zapewniać bezkarność w każdym przypadku niewymuszonego z zewnątrz odstąpienia od dokonania. Ponadto - jak zauważa M. Szerer - szkoda pokrzywdzonej przestępstwem zgwałcenia jest nie do powetowania i nie może jej naprawić żadne staranie się sprawcy, jednak nie można doznanego przez ofiarę poczucia skrzywdzenia lekceważyć pochopnym zapewnieniem bezkarności, nie dającym żadnych gwarancji ${ }^{20}$. A. Spotowski uważa, że prawo karne nie powinno premiować zachowań moralnie ujemnych. Autor dodaje, że sformułowanie stosownego przepisu bynajmniej nie przeszkadza włączeniu do pojęcia dobrowolności elementów oceny motywów; jest ono bowiem tak lakoniczne, że nie przesądza jednoznacznie o kierunku interpretacji, a ogólne założenia naszego prawa karnego wręcz skłaniają - zdaniem A. Spotowskiego - do przyjęcia kierunku normatywnego, związanego z oceną doniosłości prognostycznej zachowania sprawcy po odstąpieniu. Dlatego też proponuje on, aby przy ustalaniu dobrowolności kryterium stanowiło takie zachowanie sprawcy, które przekonuje, że chce on przestrzegać porządku prawnego ${ }^{21}$. Należy zauważyć,

17 W. Kubala: Problematyka czynnego żalu w orzecznictwie Sądu Najwyższego. PP 1981, nr 3, s. 29-34 oraz 40-42.

18 A. Stefański: Dobrowolne odstapienie od usiłowania. Prok. i Pr. 1996, nr 4, s. 112 115.

19 Wyrok SA w Krakowie z dnia 15 kwietnia 2009 r., II AKa 45/09, LEX nr 527435.

${ }^{20}$ M. SZERER: „Dobrowolne” odstapienie od usiłowania. NP 1977, nr 5, s. 627.

${ }^{21}$ A. Spotowsкi: O odstapieniu od usiłowania..., s. 94. 
że wszystkie zaproponowane ujęcia normatywne obciążone są podstawową wadą - są efektem wykładni zwężającej. A taka wykładnia, gdy odnosi się do okoliczności wyłączających odpowiedzialność karną, zawsze działa na niekorzyść sprawcy. Trzeba zatem stwierdzić, parafrazując przytoczoną wcześniej wypowiedź M. Szerera, że w tekście współczesnego przepisu art. 15 § 1 k.k. nie ma nic, co by upoważniało do zwężającej interpretacji tego przepisu.

Zupełnie odrębnym problemem są natomiast trudności z ustaleniem, czy w konkretnym stanie faktycznym mamy do czynienia $\mathrm{z}$ dobrowolnością. Z. Kubec wskazywał, że ustalenie, czy odstąpienie od usiłowania było dobrowolne czy też nie, będzie zawsze trudną kwestią faktu, a rozstrzygnięcie będzie zależało od ustalenia, co miało decydujące znaczenie: wola sprawcy czy okoliczności zewnętrzne ${ }^{22}$. O trudnościach dokonania takiej oceny może świadczyć następujący judykat: zdaniem SN „brak jest podstaw do przyjęcia, iż skazany dobrowolnie odstąpił od dokonania czynu, jeżeli z ustaleń sądu wynika, że przyczyną zaniechania dalszego jego ataku była najpierw zdecydowana obrona pokrzywdzonej, a później jej obietnica, iż poda policji, że zaatakował ją kto inny oraz jeżeli dopiero po uchwyceniu ostrza noża przez pokrzywdzoną i wyrwaniu go z ręki skazanego doszło najpierw do skierowania przez skazanego ręki pokrzywdzonej wraz z nożem w jego stronę, a po obietnicy co do tego, co powie policji, do dalszych działań - wezwania pogotowia, oddania, a następnie umycia noża" ${ }^{\prime 3}$. Warto odnotować, że w przypadku przestępstwa zgwałcenia problem oceny dobrowolności czynnego żalu jest szczególnie trudny. W. Radecki pisał, w 1974 r., mając świadomość możliwości wywołania kontrowersji, że jeżeli obawa sprawcy przed zarażeniem się chorobą weneryczną zadecydowała o tym, że odstąpił on od czynu, to można oceniać jego odstąpienie jako niedobrowolne. W uzasadnieniu autor ten podawał, że czymś innym jest obawa przed karą (w miarę zgodnie przyjmowana jako okoliczność niewyłączająca dobrowolności ${ }^{24}$ ), a czymś innym obawa przed ubocznymi skutkami fizycznymi przestępstwa ${ }^{25}$.

22 Z. Kubec: Kilka uwag..., s. 565-567.

${ }_{23}$ Postanowienie SN z dnia 24 listopada 2011 r., V KK 274/11, LEX nr 1103635.

${ }^{24}$ Por. np.: S. ŚLIwIŃski: Polskie prawo karne..., s. 309.

25 Por. np.: W. RADECKI: Usiłowanie zgwatcenia $w$ świetle przepisów kodeksu karnego. NP 1974, nr 12, s. 1619. Por. też jednak: A. Gubiński: Glosa do wyroku z 5 stycznia 1973 r., III KR 258/72. PiP 1974, nr 1/74, s. 175 oraz J. WARYLEWSKI. W: Kodeks karny. Część szczególna. T. I: Komentarz do artykułów 117-221. Red. A. WĄSEK. Warszawa 2006, s. 859-860, który pozytywnie odniósł się do tezy $\mathrm{SN}$, że strach przed chorobą weneryczną nie wyklucza dobrowolności, ponieważ zastosowanie instytucji czynnego żalu nie wymaga, aby motywy odstąpienia od usiłowania były moralnie dodatnie.

Najszerszy katalog okoliczności niewyłączających dobrowolność przy przestępstwie zgwałcenia przedstawił J. Leszczyński. Jego zdaniem, ze względu na cel instytucji czynnego 
Za niedobrowolne odstąpienie od zgwałcenia W. Radecki uznaje też niedyspozycję fizyczną sprawcy, natomiast może z bezkarności skorzystać sprawca, który odstąpił od zgwałcenia z obawy przed ujawnieniem czynu wobec rodziców małoletniej ofiary i jego żony ${ }^{26}$. Natomiast zdaniem SN nie traci cechy dobrowolności odstąpienie od usiłowania pod wpływem dezaprobaty wyrażonej przez osobę trzecią ${ }^{27}$. Intrygująco $\mathrm{w}$ tym kontekście musi brzmieć pytanie o to, czy brak odwagi do dokonania czynu odbiera takiemu zachowaniu cechę dobrowolności ${ }^{28}$. Ten krótki przegląd stanowisk musi prowadzić do wniosku, że wielokrotnie autorzy nie rozróżniają, mimo składanych deklaracji, pojęć irrelewantnej motywacji i dobrowolności. A przecież zasadniczo czymś innym jest dowolna motywacja, a czymś innym dobrowolność. Znakomitą ilustracją takiego rozróżniania stać się może przykład wskazany przez S. Śliwińskiego. Pisał on bowiem, że „także wstręt, jaki sprawca poczuł, gdy stanął w obliczu czynu, może wyłączyć dobrowolne odstąpienie, ale tylko wtedy, gdy wstręt był taki, iż sprawca go przezwyciężyć nie mógł; jeżeli mógł przezwyciężyć, ale zdecydował się nie robić sobie przykrości, odstąpienie będzie dobrowolne"29. Podobne stanowisko wyraził SN, konstatując, że można mówić o dobrowolności, jeśli „sprawca nie musiał poddać się wspomnianemu wpływowi, który w świetle doświadczenia życiowego nie stanowił przyczyny decydującej o odstąpieniu, lecz tylko stwarzał jeden z bodźców do rezygnacji" ${ }^{30}$. Powyższe konstatacje uprawniają do wniosku, że tworzenie katalogów okoliczności wyłączających i niewyłączających dobrowolność jest nieuzasadnione ${ }^{31}$ i wręcz niemożliwe. Każdą z takich okoliczności ocenić należy w kontekście konkretnego sprawcy i w konkretnej sytuacji. Mówiąc krótko, odpowiedzieć nale-

żalu (brak dokonania), do sytuacji takich należy: lęk przed karą, obawa kompromitacji, lęk przed zarażeniem się chorobą weneryczną, nagłe uczucie wstrętu do osoby gwałconej, wywołane na przykład tym, że osoba ta jest brudna, miesiączkuje, cierpi na chorobę skórną, jest powalana kałem albo zalana moczem - J. LeszCZYŃski: Z problematyki usiłowania $i$ dokonania przestępstwa zgwatcenia. NP 1975, nr 9-10, s. 1450.

26 W. RADECKI: Usiłowanie zgwatcenia..., s. 1619-1620.

27 Wyrok SN z dnia 5 stycznia 1973, III KR 258/72, OSNKW 7-8/73, poz. 92.

28 W. Maкоwsкi: Kodeks karny. Komentarz. Warszawa 1937, s. 123 za: S. ŚLIWIŃski: Polskie prawo karne..., s. 307.

${ }^{29}$ S. ŚLIwIŃski: Polskie prawo karne..., s. 307. Podobny pogląd wyraził F. Liszt, który twierdził, że dobrowolność winna mieć swoje źródło tylko w woli sprawcy, a bez znaczenia jest to, co tę wolę ukształtowało - obawa, litość czy chłodna kalkulacja zysków i strat - K. TкасZYк: Kilka uwag na temat podmiotowych i przedmiotowych warunków czynnego żalu na gruncie kodeksu karnego z 1997 r. W: Kodeks karny i kodeks postępowania karnego po dziesięciu latach obowiazywania. Ocena i perspektywa zmian. Red. M. MozGawA, K. DuDKa. Warszawa 2009, s. 114-143.

${ }^{30}$ Wyrok SN z dnia 5 stycznia 1973, III KR 258/72, OSNKW 7-8/73, poz. 92.

31 Por. np.: D. GajDus: Czynny żal w polskim prawie karnym. Toruń 1984, s. 62. 
ży na pytanie, czy dany sprawca mógł oprzeć się danej okoliczności (niezależnie, czy będzie to brak odwagi czy strach przed karą, wstręt, obecność innych osób itp.). Podzielić więc należy pogląd A. Gubińskiego, że w kwestii odstąpienia od usiłowania nie sposób wytyczyć generalne zasady dotyczące oceny jego dobrowolności. W każdym wypadku winna być ona dokonywana w świetle niepowtarzalnych okoliczności konkretnego zdarzenia ${ }^{32}$.

Problem zatem, który rodzi się przy przesłance dobrowolności, jawi się bardziej jako problem praktyczny, a nie teoretyczny; trudności z nim związane mają charakter dowodowy, a nie interpretacyjny. Stąd - jak się wydaje - tak problematyczny kazus strachu przed wykryciem czy karą, rodzący wątpliwości co do uchylania dobrowolności. E. Kunze powiedział, że trudno jest na ogół ustalić przestępny charakter czynności przygotowawczych, a także to, czy sprawca przygotowania rzeczywiście od niego odstąpił. Pojawić się mogą poważne trudności z weryfikacją prawdomówności oskarżonego, który powołuje się na to, że dobrowolnie odstąpił od kontynuowania iter delicti ${ }^{33}$. Podobną tezę można sformułować odnośnie do czynnego żalu okazanego na etapie usiłowania.

Niezależnie bowiem od przyjętej koncepcji woli człowieka, po odrzuceniu poglądów skrajnych (czystego determinizmu i indeterminizmu), zawsze staniemy przed problemem oceny, czy odstąpienie od dokonania mieściło się w marginesie swobody czy było całkowicie zdeterminowane określonymi czynnikami. Zadanie staje się tym trudniejsze, że zarówno wola, jak i czynniki ją ograniczające (lub znoszące) ostatecznie mają charakter skrajnie subiektywny $\mathrm{i}$ - mimo wszystko - nieweryfikowalny z zewnątrz. Trudno również, z oczywistych względów, opierać się wyłącznie na wyjaśnieniach sprawcy. Dlatego też W. Dziedziak wskazywał, iż „zajmując się motywacją, dotykamy zjawisk należących do intymnego świata wewnętrznego osoby. Rozważania nad motywami ludzkich czynów nie są i nie mogą być sprawą łatwą. Jak bowiem wejrzeć do »środka człowieka«, do »jego duszy« i przekonać się, co nim kieruje. Patrząc z zewnątrz na cudze zachowanie, nie można przecież w sposób pewny stwierdzić, jakimi motywami zachowanie to było powodowane. Przeżycia innych ludzi są zasadniczo nieobserwowalne dla zewnętrznego badacza. Stwierdzić można tylko działanie, a nie skłaniające do niego czynniki. Bywa też, że motywy są aktualnie nieuświadamiane, tzn. że człowiek może nie zdawać sobie sprawy z tego, co go skłania do wykonywania takich czy innych działań. Zresztą człowiek sam może niekiedy mylić się co do kierujących

32 A. Gubiński: Glosa do wyroku z 5 stycznia 1973 r..., s. 175.

${ }_{33}$ E. Kunze: Przygotowanie przestępstwa $w$ ujęciu polskiego prawa karnego. Poznań 1991, s. 106. 
nim motywów. W świetle odkryć psychologii współczesnej, a zwłaszcza psychoanalizy, dopuszcza się, iż poznanie własnych mechanizmów psychicznych może być poznaniem błędnym. Tak więc analiza i ocenianie motywów ludzkich jest materią bardzo delikatną, a nawet ryzykowną"34. Powtórzyć więc raz jeszcze należy pogląd A. Gubińskiego, że w przypadku czynnego żalu nie sposób wytyczyć generalne zasady dotyczące oceny jego dobrowolności - należy jej dokonywać w świetle niepowtarzalnych okoliczności konkretnego zdarzenia ${ }^{35}$. Przydatne mogłoby się wydawać rozwiązane zaproponowane - 80 lat temu - przez SN, który stwierdził, że „zachodzi brak cechy »dobrowolnego odstąpienia od działania «, jeżeli zewnętrzne okoliczności wpłynęły w ten sposób na wolę sprawcy przymusowo, że według doświadczenia życia praktycznego [podkreślenie O.S.], te właśnie zewnętrzne okoliczności usunęły duchową podnietę, która ukształtowała już była wolę popełnienia przestępstwa" ${ }^{36}$. Wydaje się jednak, że ocena kwestii wolności woli w oparciu o doświadczenie życiowe sędziego (prokuratora) mogłaby być bardzo zawodna, czego znakomitą ilustracją mogą być wskazywane w piśmiennictwie (i przedstawione wcześniej) motywy odstąpienia od dokonania przestępstwa o charakterze seksualnym. Jest bowiem faktem oczywistym, że indywidualizm i olbrzymia różnorodność w ocenie siły wpływu na wolę człowieka dotyczy wszystkich jego sfer życiowych - to, co dla jednych jest nie do zniesienia, inni są w stanie zaakceptować. Dokonując oceny dobrowolności, nie można też - w moim przekonaniu - opierać się na, często stosowanym w prawie karnym, modelu tzw. wzorcowego (czy przeciętnego) obywatela. I tak jak model ten musi zawodzić w określaniu reakcji emocjonalnych w sytuacjach zagrożenia ${ }^{37}$, tak samo wpływ czynników zewnętrznych jest zawsze zindywidualizowany, zależny od cech psychicznych i właściwości człowieka, jego hierarchii wartości i potrzeb. Podsumowaniem rozważań dotyczących dobrowolności w kontekście wolnej woli człowieka niech stanie się teza SN, wyrażona w wyroku z dnia 27 stycznia 1966 r., zgodnie z którą dobrowolność to świadomość możliwości kontynuowania przestępstwa i świadoma, nieprzymuszona wola rezygnacji z dalszego osiągnięcia zamierzonego celu ${ }^{38}$.

34 W. DzIEDzIaK: Dziatanie motywacyjne sankcji prawnych i moralnych. „Studia Iuridica Lublinensia" 2005, t. 5, s. 16.

35 A. Gubiński: Glosa do wyroku z 5 stycznia 1973 r..., s. 175.

${ }^{36}$ Wyrok SN z dnia 4 czerwca 1934 r., 3 K. 573/34, OSN KZP XII/34, poz. 305, s. 534.

37 Por.: M. SZAFRANIEC: Przekroczenie granic obrony koniecznej $w$ polskim prawie karnym. Kraków 2004, s. 139.

${ }_{38}$ Wyrok SN z dnia 27 stycznia 1976 r., IV KR 322/75, nie publ., cyt. za: A. STEFAŃSKI: Dobrowolne odstapienie od usitowania. Prok. i Pr. 1996, nr 4, s. 111. 
Zatem skoro sprawca mógł - jak przyjął w przywołanej na początku uchwale $\mathrm{SN}$ - popełnić czyn zabroniony, albowiem znajdował się $\mathbf{w}$ jego zasięgu „przedmiot, który należy do zbioru desygnatów znamienia przedmiotu czynności wykonawczej typu czynu zabronionego, do którego zmierzał" (co stanowi usiłowanie udolne), to rezygnacja $\mathrm{z}$ niego była całkowicie dobrowolna i przesłanki przewidziane $\mathrm{w}$ przepisie art. $15 \S 1$ k.k. zostały spełnione.

Warto przy tym zauważyć, że ponieważ istotą dobrowolności jest możliwość dokonania czynu zabronionego, a istotą usiłowania nieudolnego jest brak możliwości dokonania czynu zabronionego, da się odnotować prostą zależność: im szersze znaczenie/zakres nadamy usiłowaniu nieudolnemu, tym węższa będzie możliwość czynnego żalu, o ile to samo zdarzenie jest przyczyną nieudolności i „rezygnacji” sprawcy z dokonania czynu zabronionego. I odwrotnie - im węższe znaczenie/zakres nadamy usiłowaniu nieudolnemu, tym szersza będzie możliwość czynnego żalu, o ile to samo zdarzenie jest przyczyną nieudolności i rezygnacji sprawcy z dokonania czynu zabronionego. Dokonując więc karnoprawnej oceny czynu, uważać należy, aby nie popaść w sprzeczność - uznając udolność usiłowania, a tym samym możliwość dokonania, i równocześnie odmówić dobrowolności, ze względu na brak możliwości jego popełnienia. Wydaje się, że ta sama przyczyna nie może równocześnie wykluczać usiłowania nieudolnego oraz dobrowolności czynnego żalu, a takie rozwiązanie zaproponował $\mathrm{SN}$ w uchwale będącej punktem wyjścia niniejszych rozważań ${ }^{39}$.

Powyższe rozważania teoretyczne przełożyć można na bardziej wyrazisty przykład ilustrujący tę zależność. Sprawca, mający zamiar zabić X, wchodzi do pokoju z naładowaną i wyciągniętą bronią, gdzie spostrzega,

39 W podobnym duchu wypowiedział się wcześniej SA w Katowicach, który skonstatował: „Nie budzi wątpliwości, że usiłowanie nieudolne charakteryzuje się brakiem zagrożenia dobra prawnego, na które skierowany jest czyn sprawcy, m.in. z uwagi na brak przedmiotu nadającego się do popełnienia na nim owego czynu zabronionego, co wiązać trzeba z działaniem w błędnym o powyższej okoliczności przekonaniu, która obiektywnie powoduje niemożliwość popełnienia czynu zabronionego. O powyższej niemożliwości realizacji znamion zbrodni rozboju nie stanowi natomiast sytuacja, w której oskarżony, posługując się $\mathrm{w}$ celu dokonania kradzieży metodami wynikającymi z przepisu art. $280 \S 2$ k.k., nie zabiera pokrzywdzonemu posiadanych rzeczy ruchomych, w tym pieniędzy - mimo realnych ku temu możliwości - tylko dlatego, że ich wartość odbiega od oczekiwanych przez niego. Odstąpienie w takim wypadku od kradzieży, które nie jest dobrowolne w rozumieniu art. 15 § 2 k.k., jako że jest wynikiem sytuacji zewnętrznej, związanej z brakiem możliwości materialnego zaspokojenia sprawcy w sposób przez niego pożądany, a nie wewnętrznych przemyśleń o celowości popełnienia w ogóle przestępstwa, uznane być musi za zachowanie zmierzające bezpośrednio do dokonania, które nie następuje z powyższej przyczyny, na które powołuje się przepis art. 13 § 1 k.k.” - Wyrok SA w Katowicach z dnia 28 lutego 2002 r., II AKa 549/01, LEX nr 56778. 
że nie ma X, jest tylko Y, którego nie zabija. Zdaniem $\mathrm{SN}$ byłoby to usiłowanie udolne (sprawca mógł zabić inną obecną w pokoju osobę jako desygnat pojęcia „człowiek”), ale jego rezygnacja nie była dobrowolna. W moim przekonaniu było to usiłowanie nieudolne, przy czym zastosowanie przepisu art. $15 \S 1$ k.k. jest niemożliwe.

Na marginesie zatem należy zauważyć, że „spór” (prowadzony np. na sali rozpraw) o szerokie rozumienie usiłowania nieudolnego jako rozwiązania korzystniejszego dla sprawcy niekoniecznie jest racjonalny. To przyjęcie usiłowania udolnego z poniechaniem zamiaru może być najkorzystniejszą opcją dla oskarżonego. Powtórzyć zatem wypada, że jeśli to przyczyna nieudolności stała się przyczyną przerwania iter delicti, to z pewnością zachowanie takie nie ma charakteru dobrowolnego (de facto nie można mówić o poniechaniu, skoro dokonanie było niemożliwe). Gdyby jednak nie zgodzić się z tezą przywoływanej uchwały i przyjąć, iż w omawianych sytuacjach - brak konkretnego przedmiotu, objętego zamiarem sprawcy - w grę wchodzi usiłowanie nieudolne, rozważyć należy problem czynnego żalu przy usiłowaniu nieudolnym.

Konieczne staje się udzielenie odpowiedzi na pytanie, czy sprawca usiłowania nieudolnego może skorzystać z bezkarności przewidzianej $\mathrm{w}$ art. $15 \S 1$ k.k. W piśmiennictwie prezentowane są dość zgodne opinie odnośnie do czynnego żalu sprawcy usiłowania nieudolnego. S. Śliwiński proponuje dla dokonania karnoprawnej oceny czynnego żalu sprawcy usiłowania nieudolnego sięgnąć, poprzez analogię, do przepisu art. 13 k.k. z 1932 r. $^{40}$. Według K. Indeckiego i A. Liszewskiej czynny żal nie dotyczy usiłowania nieudolnego, ale akceptują oni - powołując się na K. Buchałę, W. Woltera i A. Wąska - korzystanie mutatis mutandi z dobrodziejstwa art. $15 \S 1$ k.k. ${ }^{41}$. Również zdaniem W. Wróbla i A. Zolla z wykładni systemowej wynika, że należy przyjąć możliwość stosowania art. 15 § 1 i 2 k.k. również przy usiłowaniu nieudolnym ${ }^{42}$. Przeszkód w stosowaniu art. 15 k.k. do usiłowania nieudolnego nie widzi też R. Zawłocki, powołując się na analogię ${ }^{43}$, podobnie jak K. Tkaczyk ${ }^{44}$. Natomiast zdaniem Z. Kubeca, na tle przepisów Kodeksu karnego z 1932 r., wyłączyć należy możliwość

40 S. ŚLIwiŃski: Polskie prawo karne materialne..., s. 321. Podobnie - D. GajDus: Czynny $\dot{z} a l . . .$, s. 99.

${ }^{41}$ K. IndeCKI, A. LiszewsKa: Prawo karne materialne. Nauka o przestępstwie, karze i środkach penalnych. Warszawa 2002, s. 225. Por. też: A. LIszewsKA. W: Nauka o przestępstwie. Zasady odpowiedzialności. System prawa karnego. T. 3. Red. R. DęвSKI. Warszawa 2013, s. 793.

${ }^{42}$ W. Wróbel, A. Zoll: Polskie prawo karne..., s. 238.

${ }^{43}$ R. ZawŁocki. W: Kodeks karny. Część ogólna. T. I: Komentarz do artykułów 1-31. Red. M. KrólIKowsKi, R. ZAWŁocKi. Warszawa 2011, s. 634-635.

${ }^{44} \mathrm{~K}$. ТкасZYк: Instytucja czynnego żalu $w$ prawie karnym $w$ ujęciu prawnoporównawczym. Przemyśl 2008, s. 155-156. 
stosowania analogii, proponując de lege ferenda takie brzmienie przepisu, które wątpliwości tego rodzaju by usunęło ${ }^{45}$.

Przede wszystkim należy zauważyć, że w literaturze przedmiotu często występuje zbytnie uproszczenie problemu. Nie można udzielić jednoznacznej odpowiedzi na pytanie, czy sprawca nieudolnego usiłowania może skorzystać z konstrukcji przewidzianej w art. 15 k.k. W grę bowiem wchodzą dwie różne sytuacje ${ }^{46}$, w zależności od przyczyny podjęcia decyzji o braku kontynuacji iter delicti.

Pierwsza z nich to sytuacja, gdy to przyczyna nieudolności - rozpoznana przez sprawcę - stała się powodem przerwania drogi przestępnej. $\mathrm{Z}$ pewnością zaniechanie takie nie ma charakteru dobrowolnego (de facto nie można mówić o poniechaniu, skoro do dokonania nie doszło, ponieważ było niemożliwe). W takim przypadku nie może być mowy o czynnym żalu sprawcy, a tym samym o możliwości skorzystania przez niego z bezkarności.

Zupełnie inaczej wygląda ocena $\mathrm{w}$ drugiej sytuacji, tzn. gdy podjęcie decyzji o poniechaniu drogi przestępnej następuje przy równoczesnym nieuświadomieniu sobie niemożliwości dokonania czynu zabronionego. Sprawca podający błędnie zamiast trucizny cukier do herbaty, który następnie zawozi pokrzywdzonego do szpitala na płukanie żołądka, zasługuje - in opinio communis ${ }^{47}$ - na bezkarność w nie mniejszym stopniu niż sprawca podający truciznę i powodujący swoim intencjonalnym zachowaniem, że do śmierci nie doszło. Równocześnie prezentowany jest pogląd o niemożliwości stosowania wprost w takim przypadku przepisu art. $15 \S 1$-skoro sprawca ani nie odstapił od dokonania (wobec usiłowania zakończonego), ani nie zapobiegł skutkowi (wobec braku możliwości jego wystąpienia) i stąd konieczność sięgnięcia po analogię. Rozwiązując ten problem, przede wszystkim należy pamiętać o regulacji przewidzianej w przepisie art. $60 \S 2$ ust. 2 k.k. Zezwala on na nadzwyczajne złagodzenie kary, kiedy nawet najniższa kara przewidziana za przestępstwo byłaby niewspółmiernie surowa ze względu na postawę sprawcy, zwłaszcza gdy czynił starania o naprawienie szkody lub o jej zapobieżenie. Ponieważ to właśnie postawa sprawcy uzasadniać ma degresję w wymiarze środków reakcji karnej, dalsze dookreślenia stanowią tylko egzemplifikację pozy-

45 Z. Kubec: Kilka uwag na temat odstapienia..., s. 562-563 i 568.

${ }^{46}$ Por. też: A. Zoll. W: Kodeks karny. Część ogólna. Komentarz LEX. T. I: Komentarz do art. 1-116 k.k. Red. A. Zoll. Warszawa 2012, s. 275; A. LiszewsKA. W: Nauka o przestępstwie..., s. 794.

47 Por. np.: S. ŚLIWIŃsKI: Polskie prawo karne materialne..., s. 321; A. WĄSEK: Kodeks karny. Komentarz. T. I: art. 1-31. Gdańsk 1999, s. 219; K. InDECKI, A. LiszewsKa: Prawo karne materialne..., s. 225. 
tywnie ocenianej jego postawy ${ }^{48}$. Nie powinno być zatem wątpliwości, że błędne decyzje odnośnie do (niekoniecznego) czynnego żalu nie odejmują postawie sprawcy ocen pozytywnych. Równocześnie jednak odnotować należy, że konsekwencje karnoprawne czynnego żalu przewidzianego $\mathrm{w}$ przepisie art. $60 \S 2$ ust. 2 są daleko mniej korzystne niż te przewidziane $\mathrm{w}$ art. $15 \S 1$ k.k.

Zadać jednak należy pytanie, czy rzeczywiście, jak twierdzi A. Wąsek, kwestia czynnego żalu przy usiłowaniu nieudolnym nie jest uregulowa$n \mathrm{a}^{49}$. W moim przekonaniu pogląd taki jest nieuprawniony, a argumentu dostarcza wykładnia językowa. Przepis art. $15 \S 1$ k.k. stanowi, iż „nie podlega karze za usiłowanie", natomiast przepis art. 13 § 2 k.k., odnoszący się do usiłowania nieudolnego, wskazuje, że „usiłowanie zachodzi także wtedy". Nie ma zatem żadnych ograniczeń normatywnych, aby przepis art. 15 k.k. stosować również do usiłowania nieudolnego ${ }^{50}$. Inna interpretacja naruszałaby zakaz wykładni lege non distinguente nec nostrum est distinguere, co prowadziłoby de facto do zawężenia pojęcia usiłowania na gruncie instytucji czynnego żalu (tylko do usiłowania udolnego). Ponieważ mówimy o instytucji wyłączającej odpowiedzialność karną, naruszenie tego zakazu, ze względu na funkcję gwarancyjną prawa karnego, jest niedopuszczalne (wykładnia taka musiałaby prowadzić do pogorszenia sytuacji sprawcy). Są jednak autorzy, którzy brak możliwości zastosowania wprost art. 15 k.k. w stosunku do sprawcy usiłowania nieudolnego uzasadniaja specyficznym charakterem usiłowania nieudolnego. $Z$ jednej bowiem strony jest to usiłowanie ukończone, co nie pozwala na uznanie, że sprawca w ramach czynnego żalu odstąpił od dokonania, z drugiej - trudno mówić o zapobieganiu czemuś, co nigdy by nie nastąpiło. Rozwiązanie tego problemu staje się zupełnie proste, gdy przyjmie się koncepcję braku znaczenia podziału na usiłowanie ukończone i nieukończone na potrzeby klauzuli bezkarności jako konsekwencji czynnego żalu.

$\mathrm{W}$ przepisie art. $15 \S 1 \mathrm{k} . \mathrm{k}$. wskazane są jedynie wymogi uprawniające do bezkarności w postaci: 1) odstąpienia, gdy jest to wystarczające dla braku dokonania, lub 2) zapobieżenia, gdy dla braku dokonania, ze względu na zainicjowany związek kauzalny, konieczne jest podjęcie przeciwakcji. Usiłowanie nieudolne nie inicjuje związku kauzalnego, zatem nie jest konieczne zapobieżenie. W takim bowiem przypadku wystarczy poniechanie drogi przestępnej. Podkreślić jednak należy, że to poniechanie (odstąpienie) musi być intencjonalne - (nowym) zamiarem sprawcy

48 Por.: J. Raglewski: Model nadzwyczajnego złagodzenia kary w polskim systemie prawa karnego (analiza dogmatyczna w ujęciu materialnoprawnym). Kraków 2008, s. 196-202.

49 A. WĄsEK: Kodeks karny..., s. 219. Podobną tezę, wcześniej, głosili: W. Wolter: Funkcja błędu w prawie karnym. Warszawa 1965, s. 130 oraz D. GajDus: Czynny żal..., s. 98.

${ }^{50}$ Por. też: J. MajewsKi: O różnicy i granicy między usiłowaniem..., s. 24. 
jest brak dokonania. Czynności podejmowane przez sprawcę usiłowania nieudolnego (to prawda - zbyteczne) potwierdzają w świecie zewnętrznym jego zamiar odstąpienia od dokonania. Nie ma zatem racji A. Wąsek. W moim przekonaniu regulacja art. 15 k.k. całkowicie wystarcza do dokonania karnoprawnej oceny czynnego żalu w przypadku usiłowania nieudolnego i może być stosowana wprost ${ }^{51}$.

W tym rodzić miejscu musi się pytanie, jakiej karnoprawnej oceny należy dokonać, gdy sprawca usiłowania nieudolnego w trakcie usiłowania zorientował się, że działa w błędzie i świadomie nie kontynuuje już skuteczniejszej akcji. Przykładowo po podaniu cukru zamiast trucizny wobec braku „efektu” stwierdza, że pomylił opakowania. Truciznę może z łatwością podać (posiada ją), a sam pokrzywdzony nie zorientował się, że ktoś usiłował go zabić - czy w takim przypadku jest możliwy czynny żal skutkujący bezkarnością? Ponownie sytuacja, w której sprawca nie zainicjował związku kauzalnego powoduje, że wystarczy intencjonalne odstąpienie od drogi przestępnej, zatem świadome (,powtórne”) niepodanie trucizny. Wydaje się przy tym, że ewentualne problemy dowodowe nie będą większe niż przy klasycznym odstąpieniu.

Pojawić się jednak może problem braku pewnego filtra, pozwalającego ocenić charakter podjętej przeciwakcji w przypadku usiłowania nieudolnego, a tym samym potwierdzić zamiar poniechania iter delicti: cokolwiek sprawca zrobi, jego zachowanie zawsze będzie „skuteczne” (nie nastąpi bowiem dokonanie). W przypadku usiłowania udolnego takim naturalnym filtrem jest brak dokonania (przy skutecznym czynnym żalu) lub podjęcie starań, wykluczające działania pozorne (przy nieskutecznym czynnym żalu). Problem bowiem leży w swoistym krzyżowaniu się form czynnego żalu - sprawca podejmuje czynności zapobiegawcze, będące de facto odstapieniem od dokonania. Jedynym, jak się wydaje, kryterium pozwalającym na dokonanie oceny zachowania sprawcy (poza oczywiście brakiem dokonania) będzie dobrowolność, która jednak - mam tego świadomość - nie jest w pełni adekwatnym kryterium do odrzucenia zachowań pozornych. Jeśliby wrócić do wcześniejszego przykładu, to ilustracją tego problemu będzie następująca sytuacja - sprawca, omyłkowo, podaje cukier zamiast trucizny, pokrzywdzony, który zorientował się o podaniu „trucizny”, błaga sprawcę o udzielenie pomocy, sprawca nie zabiera jednak pokrzywdzonego do szpitala, ale dla „świętego spokoju” podaje mleko, o którym czytał, że ma właściwości odtruwające. Skutku w postaci śmierci człowieka rzeczywiście nie ma i być nie mogło. Przyjęcie, iż w tym przypadku wystarczającym wymogiem jest odstąpienie od dokonania,

51 Szerzej na ten temat zob. O. Sitarz: Usiłowanie ukończone i nieukończone. Próba nowego spojrzenia. PiP 2011, nr 6. 
uniemożliwia ocenę sprawcy poprzez pryzmat charakteru podjętych działań. Ostateczną ocenę oprzeć trzeba na definicji dobrowolności, a przede wszystkim na realności zamiaru braku dokonania.

Konkludując całe rozważania, podkreślić należy, iż przedstawione w uchwale SN rozstrzygnięcie to próba „sprawiedliwego i słusznego” rozwiązania kwestii „nieusatysfakcjonowanego” sprawcy, który zrezygnował z dokonania zamierzonego czynu zabronionego. Bezkarność w takich sytuacjach wydaje się całkowicie niezasadna. Takie podejście spowodowało, że SN podjął uchwałę, która w uzasadnieniu jest sprzeczna wewnętrznie.

\section{Bibliografia}

\section{Literatura}

ANDREJEW I.: Polskie prawo karne. Warszawa 1971.

DzIEDZIaK W.: Działanie motywacyjne sankcji prawnych $i$ moralnych. „Studia Iuridica Lublinensia" 2005. T. 5.

Gajdus D.: Czynny żal w polskim prawie karnym. Toruń 1984.

GIEzeK J.: Glosa do uchwały Sądu Najwyższego z dnia 20 listopada 2001 r., sygn. I KZP 36/2000. Prok. i Pr. 2001, nr 9.

GIEZEK J. W: Kodeks karny. Część ogólna. Komentarz. Red. J. GIEZEK. Warszawa 2012. GubińsKi A.: Glosa do wyroku z 5 stycznia 1973, III KR 258/72. PiP 1974, nr 1/74. Hatas R.G. W: Prawo karne. Red. A. Grześ́xowiak. Warszawa 2012.

InDECKI K., LIsZEwsKa A.: Prawo karne materialne. Nauka o przestępstwie, karze $i$ środkach penalnych. Warszawa 2002.

Kubala W.: Glosa do wyroku Izby Karnej Sądu Najwyższego z 1 sierpnia 1975 r. Pal. 1976, nr 4-6.

Kubala W.: Problematyka czynnego żalu $w$ orzecznictwie Sadu Najwyższego. PP 1981, nr 3.

Kubec Z.: Kilka uwaga na temat odstapienia od usiłowania. PiP 1969, nr 3.

KunZE E.: Przygotowanie przestępstwa w ujęciu polskiego prawa karnego. Poznań 1991.

LESZCZYŃSKI J.: Z problematyki usiłowania $i$ dokonania przestępstwa zgwatcenia. NP 1975, nr 9-10.

LiszewsKa A. W: Nauka o przestępstwie. Zasady odpowiedzialności. System prawa karnego. T. 3. Red. R. DębSKI. Warszawa 2013.

MAJEWSKI J.: O różnicy i granicy między usiłowaniem udolnym a usiłowaniem nieudolnym. W: Formy stadialne i postacie zjawiskowe popetnienia przestępstwa. Materiaty III Bielańskiego Kolokwium Karnistycznego. Red. J. MajEwsKI. Toruń 2007.

Nowe kodeksy karne - z 1997 r. z uzasadnieniami. Kodeks karny. Kodeks postępowania karnego. Kodeks karny wykonawczy. Red. I. Fredrich-MichalsKa, B. StACHURSKA-MARCIŃCZAK. Warszawa 1997.

RADECKI W.: Prawne i moralne oceny czynnego żalu. Pal. 1976, nr 12.

RADECKI W.: Usiłowanie zgwatcenia $w$ świetle przepisów kodeksu karnego. NP 1974, nr 12. 
RaglewsKi J.: Dobrowolne odstąienie od czynu jako przesłanka instytucji czynnego żalu. Prok. i Pr. 1997, nr 3.

RAGLEWSKI J.: Model nadzwyczajnego złagodzenia kary w polskim systemie prawa karnego (analiza dogmatyczna w ujęciu materialnoprawnym). Kraków 2008.

RejMAN G.: W kwestii dobrowolnego odstapienia od usiłowania. NP 1969, nr 3.

SITARz O.: Czynny żal związany z usiłowaniem w polskim prawie karnym. Analiza dogmatyczna i kryminalnopolityczna. Katowice 2015.

Sitarz O.: Usiłowanie ukończone $i$ nieukończone. Próba nowego spojrzenia. PiP 2011, nr 6.

SPOTOwski A.: O odstapieniu od usiłowania. PiP 1980, nr 6.

STEFAŃski A.: Dobrowolne odstapienie od usiłowania. Prok. i Pr. 1996, nr 4.

SZAFRANIEC M.: Przekroczenie granic obrony koniecznej $w$ polskim prawie karnym. Kraków 2004.

SZERER M.: „Dobrowolne” odstapienie od usiłowania. NP 1977, nr 5.

ŚLIWIŃsKI S.: Prawo karne. Warszawa 1946.

ТкасZук K.: Instytucja czynnego żalu $w$ prawie karnym $w$ ujęciu prawnoporównawczym. Przemyśl 2008.

ТкасZҮк K.: Kilka uwag na temat podmiotowych i przedmiotowych warunków czynnego żalu na gruncie kodeksu karnego z 1997 r. W: Kodeks karny i kodeks postępowania karnego po dziesięciu latach obowiazywania. Ocena i perspektywa zmian. Red. M. Mozgawa, K. DudKa. Warszawa 2009.

Warylewski J.: Prawo karne. Część ogólna. Warszawa 2012.

WARYLEWsKi J. W: Kodeks karny. Część szczególna. T. I: Komentarz do artykutów 117-221. Red. A. WĄSEK. Warszawa 2006.

WąseK A.: Kodeks karny. Komentarz. T. I: art. 1-31. Gdańsk 1999.

Wróbel W., Zoll A.: Polskie prawo karne. Warszawa 2010.

Wolter W.: Funkcja błędu w prawie karnym. Warszawa 1965.

Wolter W.: Nauka o przestępstwie. Warszawa 1973.

ZawŁocki R. W: Kodeks karny. Część ogólna. T. I: Komentarz do artykułów 1-31. Red. M. KrólikowsKi, R. ZawıOCKI. Warszawa 2011.

Zoll A. W: Kodeks karny. Część ogólna. Komentarz LEX. T. I: Komentarz do art. 1-116 k.k. Red. A. Zoll. Warszawa 2012.

\section{Orzecznictwo}

Wyrok SN z dnia 4 czerwca 1934 r., 3 K. 573/34, OSN KZP XII/34, poz. 305.

Wyrok SN z dnia 5 stycznia 1973 r., III KR 258/72, OSNKW 7-8/73, poz. 92. Postanowienie SN z dnia 24 listopada 2011 r., V KK 274/11, LEX nr 1103635. Wyrok SA w Katowicach z dnia 28 lutego 2002 r., II AKa 549/01, LEX nr 56778. Wyrok SA w Krakowie z dnia 15 kwietnia 2009 r., II AKa 45/09, LEX nr 527435.

\section{Źródła internetowe}

Uchwała siedmiu sędziów SN z dnia 19 stycznia 2017 r., I KZP 16/16. Źródło: http://www.sn.pl/sites/orzecznictwo/Orzeczenia3/I\%20KZP\%2016-16.pdf [dostęp: 27.02.2017]. 